\title{
THE EFFECT OF NATURAL WEATHERING ON UNTREATED WOOD SURFACE
}

\author{
Eliška Oberhofnerová ${ }^{1, \diamond}$, Miloš Pánek $^{1}$, Alba García-Cimarras ${ }^{2}$
}

\begin{abstract}
As a result of contemporary ecological and sustainable movements, a number of constructions from wood, as the only renewable building material, is still increasing. In accordance with these trends, wood elements are often left untreated. The presented study is aimed to characterize and compare a surface degradation of untreated wood caused by weathering. Weathering characteristics of softwoods and hardwoods (spruce, pine, Douglas fir, larch, oak, black locust, maple, poplar and alder) during twelve months of exposure in the climatic conditions of Central Europe were determined. All the wood species were characterized by colour and gloss changes and increasing roughness. The lowest discoloration was observed for oak and the highest one for spruce wood, respectively. The lowest changes of roughness were observed for alder, the highest for spruce wood. The depth of colour changes was relatively similar among the softwoods. Regarding hardwoods, it varied more. The values of total colour changes had a significant correlation with the depth values of these colour changes. Maple, alder and poplar samples were characterized by the presence of mould and blue-stain fungi. Douglas fir wood was found to be the most liable for the formation of cracks.
\end{abstract} wood.

Keywords: Central Europe, colour changes, natural weathering, surface roughness, untreated

\section{INTRODUCTION}

Nowadays, the trend of ecological building is becoming more progressive. Wood as a renewable material is noted for some obvious advantages connected with its nature origin respecting the ecological and sustainable development. The amount of wood used both in the interior and exterior is increasing day by day. The wooden structures and elements are more often treated with natural-based surface treatments (Singh and Singh 2012) or even untreated.

When the wood is used in the exterior, there are some major issues which should be followed to reduce the effect of weathering on wood degradation. First, it is recommended to use wood materials with higher natural durability in accordance with EN 350-2 (1994). Second, a proper construction solution is required (optimal shape of wood element, covering the end parts, roof overlaps, ventilation, distance from the ground etc.). Third, the surface treatment can be used to prolong the service life of wood (Feist 1982, Brischke et al. 2006). In the case of respecting above mentioned steps, the

\footnotetext{
${ }^{1}$ Department of Wood Products and Wood Constructions, Faculty of Forestry and Wood Sciences, Czech University of Life Sciences Prague, Kamýcká, Czech Republic. panekmilos@fld.czu.cz

${ }^{2}$ ETSI Montes, Forestal y del Medio Natural, Universidad Politécnica de Madrid, Madrid, Spain. alba.gcimarras@gmail.com ${ }^{\otimes}$ Corresponding author: oberhofnerova@fld.czu.cz
}

Received: 15.08.2016 Accepted: 13.01.2017 
degradation affects only the surface layers of wood (Reinprecht 2008), which is manifested by the change of colour (Williams and Feist 1999), followed by a formation of cracks and increased roughness of the samples (Feist 1990, Ozgenc et al. 2012). The most significant weathering factors influencing the rate of degradation are solar radiation and water, acting synergistically (Tolvaj and Faix 1995, Hon and Shiraishi 2001, Müller et al. 2003). However, there are other factors which contribute to surface degradation such as temperature, dust particles, acid rain and air flow (Feist 1990, Williams 2005, Evans 2008, Teacà et al. 2013). Mainly the UV light initiates photochemical reactions, which cause decomposition of lignin, extractives and partly even hemicellulose (Feist and Hon 1984, Pandey 2005, Reinprecht 2008). Degraded compounds are leached from the wood by water (Tolvaj and Faix 1995, Pandey 2005). As the result, wood changes colour, some species turns yellow or brown, eventually, they turn into grey, which is often caused by growth of fungi and moulds (Feist 1982) and by the dust particles in air which penetrate to the porous structure of wood (Hon and Chang 1984). After leaching of UV degradation products, underlying cell layers are exposed and further eroded (Feist 1982, Williams and Feist 1999, Reinprecht 2008). Erosion is more rapid in the less dense early-wood than in latewood, which leads to an uneven and rougher surface (Williams et al. 2001). Formation of checks, split and cracks caused by moisture and temperature changes also leads to tangible surface roughness (Feist 1990, Ozgenc et al. 2013).

A lot of studies were aimed at evaluating the properties of wood treated or modified with some protective compound after natural weathering (Kropf et al. 1994, Nzokou et al. 2011, Turkoglu et al. 2015) or accelerated weathering (Tolvaj and Faix 1995, Williams et al. 2001, Temiz et al. 2005, Ozgenc et al. 2012). In these studies, the surface became rougher and darker after weathering in comparison with the initial stages. Total colour change increased with increasing exposure times in natural weathering. Despite contemporary ecological trends, significantly less studies deal with the weathering characteristics of untreated wood (Hon and Feist 1986, Tolvaj and Faix 1995, Gonzalez de Cademartori et al. 2016). Untreated wood specimens exhibited higher colour changes in the shorter time than the treated specimens (Saei et al. 2015, Turkoglu et al. 2015). The colour changes were reported strictly as a surface phenomenon, they occurred to a depth of only 0,05-2,5 mm (Feist 1990, Reinprecht 2008). Measuring the surface roughness has been already used in several studies as a tool to analyse the effects of weathering on wood surfaces (Östman 1983, Xie et al. 2008, Nzokou et al. 2011). The trend of increasing roughness value was observed in these studies. The rate of degradation is usually related to the intensity of light (Kataoka et al. 2007) and its wavelengths (MacLeod et al. 1995, Kataoka et al. 2007), the time of irradiation (Tolvaj and Faix 1995, Hon and Shiraishi 2001), the wood species (Hon and Shiraishi 2001) and climatic factors occurring during exposure (Hon and Chang 1984). In addition, it must be considered that the weathering conditions in $45^{\circ}$ south exposure are accelerated relative to vertically installed elements, e.g. claddings, and decelerated relative to horizontal surfaces, e.g. decking (Evans 1996).

This study is aimed on the evaluation and comparison of surface degradation of selected wood species during twelve months of natural weathering. The information about behaviour of untreated wood, both softwoods and hardwoods, exposed to outdoor climatic conditions is given. The change of colour, depth of these changes, change of gloss, roughness and formation of cracks and mould were investigated. The information about the depth of these changes could serve for those who is not satisfied with the grey shade of the wood and decides to sand the wood element to initial colour. Above mentioned information, important for a maintenance and service life of wood, must be provided for further effective use of wood in the exterior. 


\section{MATERIALS AND METHODS}

\section{Materials}

The experiment was carried out using three samples, all of them with dimensions $375 \times 78 \times 20 \mathrm{~mm}$ (LxTxR), from nine wood species (Table 1). In the case of heartwood species, only the heartwood was tested. Test samples were sanded with the sandpaper grit of 120. Initial characteristics of wood samples before weathering are shown in Table 1.

Table 1. The mean values of density, colour parameters $L^{*}, a^{*}$ and $b^{*}$, gloss and roughness parameter Ra of samples at the beginning of the weathering test.

\begin{tabular}{|c|c|c|c|c|c|c|c|}
\hline \multirow{2}{*}{ Wood species (Latin name) } & \multirow{2}{*}{$\begin{array}{l}\text { Nat. durability } \\
\text { against fungi } \\
\text { (EN 350-2) }\end{array}$} & \multirow{2}{*}{$\begin{array}{c}\text { Density [kg/ } \\
\left.\text { m }^{3}\right] \text { (ČSN } 49 \\
\text { 0108) }\end{array}$} & \multicolumn{3}{|c|}{$\begin{array}{c}\text { Colour parameters } \\
\text { (EN 927-3) }\end{array}$} & \multirow[t]{2}{*}{ Gloss } & \multirow{2}{*}{$\begin{array}{c}\mathrm{Ra}[\mu \mathrm{m}] \\
\text { (ISO } \\
\mathbf{4 2 8 8})\end{array}$} \\
\hline & & & $L^{*}$ & $a^{*}$ & $b^{*}$ & & \\
\hline $\begin{array}{l}\text { Norway spruce } \\
\text { (Picea abies L. Karst) }\end{array}$ & 4 & 533 & $\begin{array}{l}84,16 \\
(0,16)\end{array}$ & $\begin{array}{c}3,72 \\
(0,08)\end{array}$ & $\begin{array}{l}19,54 \\
(0,20)\end{array}$ & $\begin{array}{l}14,3 \\
(2,0)\end{array}$ & $\begin{array}{c}5,29 \\
(0,73)\end{array}$ \\
\hline $\begin{array}{l}\text { Scots Pine } \\
\text { (Pinus sylvestris L.) }\end{array}$ & $3-4$ & 698 & $\begin{array}{l}81,19 \\
(0,23)\end{array}$ & $\begin{array}{c}3,65 \\
(0,95)\end{array}$ & $\begin{array}{l}23,93 \\
(1,57)\end{array}$ & $\begin{array}{l}12,5 \\
(2,5)\end{array}$ & $\begin{array}{c}3,71 \\
(0,86)\end{array}$ \\
\hline $\begin{array}{l}\text { Douglas fir } \\
\text { (Pseudotsuga menziesii } \\
\text { (Mirb,) Franco) }\end{array}$ & 3 & 605 & $\begin{array}{l}71,82 \\
(1,03)\end{array}$ & $\begin{array}{l}11,78 \\
(0,43)\end{array}$ & $\begin{array}{l}21,68 \\
(0,57)\end{array}$ & $\begin{array}{l}10,0 \\
(1,7)\end{array}$ & $\begin{array}{c}4,43 \\
(0,33)\end{array}$ \\
\hline $\begin{array}{l}\text { English oak } \\
\text { (Quercus robur L.) }\end{array}$ & 2 & 710 & $\begin{array}{l}72,86 \\
(1,67)\end{array}$ & $\begin{array}{l}10,44 \\
(0,44)\end{array}$ & $\begin{array}{l}22,55 \\
(1,39)\end{array}$ & $\begin{array}{c}7,9 \\
(1,0) \\
\end{array}$ & $\begin{array}{c}7,23 \\
(1,78)\end{array}$ \\
\hline $\begin{array}{l}\text { Black locust } \\
\text { (Robinia pseudoacacia L.) }\end{array}$ & $1-2$ & 827 & $\begin{array}{l}66,40 \\
(0,22) \\
\end{array}$ & $\begin{array}{c}6,28 \\
(0,10) \\
\end{array}$ & $\begin{array}{l}20,45 \\
(0,44) \\
\end{array}$ & $\begin{array}{c}8,1 \\
(0,7) \\
\end{array}$ & $\begin{array}{c}4,39 \\
(0,58)\end{array}$ \\
\hline $\begin{array}{l}\text { Poplar } \\
\text { (Populus sp.) }\end{array}$ & 5 & 413 & $\begin{array}{l}70,59 \\
(1,06) \\
\end{array}$ & $\begin{array}{c}2,89 \\
(0,14)\end{array}$ & $\begin{array}{l}26,80 \\
(0,36)\end{array}$ & $\begin{array}{c}9,0 \\
(1,6) \\
\end{array}$ & $\begin{array}{c}6,24 \\
(0,40) \\
\end{array}$ \\
\hline $\begin{array}{l}\text { Sycamore maple } \\
\text { (Acer pseudoplatanus L.) }\end{array}$ & 5 & 599 & $\begin{array}{l}78,85 \\
(0,57)\end{array}$ & $\begin{array}{c}5,11 \\
(0,23)\end{array}$ & $\begin{array}{l}16,69 \\
(0,09)\end{array}$ & $\begin{array}{l}10,3 \\
(0,6)\end{array}$ & $\begin{array}{c}4,17 \\
(0,31)\end{array}$ \\
\hline $\begin{array}{l}\text { Black alder } \\
\text { (Alnus glutinosa (L.) Gaertn) }\end{array}$ & 5 & 534 & $\begin{array}{l}82,33 \\
(0,19)\end{array}$ & $\begin{array}{c}4,09 \\
(0,07)\end{array}$ & $\begin{array}{l}16,58 \\
(0,24)\end{array}$ & $\begin{array}{l}11,7 \\
(1,2)\end{array}$ & $\begin{array}{c}5,67 \\
(0,91)\end{array}$ \\
\hline $\begin{array}{l}\text { European larch } \\
\text { (Larix decidua [Mill.]) }\end{array}$ & $3-4$ & 559 & $\begin{array}{l}71,63 \\
(1,90)\end{array}$ & $\begin{array}{l}10,95 \\
(0,80)\end{array}$ & $\begin{array}{l}21,71 \\
(1,12)\end{array}$ & $\begin{array}{c}6,6 \\
(1,1) \\
\end{array}$ & $\begin{array}{c}5,01 \\
(0,50)\end{array}$ \\
\hline
\end{tabular}

Note: Mean values and Standard deviations (in parenthesis) were determined from 24 measurements of colour and gloss and from 12 measurements of roughness for each wood specie. The natural durability against fungi was determined according to 350-2 (1994), value 1-5, while 1 signifies the highest natural durability. The density (at the moisture content of $12 \%$ ) in $\mathrm{kg} /$ $\mathrm{m}^{3}$ was determined according to ČSN 490108 (1993).

\section{Natural Weathering Site}

The natural weathering test was carried out at Suchdol, Prague $\left(50^{\circ} 07^{\prime} 49,68^{\prime \prime} \mathrm{N} ; 1^{\circ} 22^{\prime} 13,87^{\prime \prime} \mathrm{E}\right.$, elevation above sea level $285 \mathrm{~m}$ ) and lasted 12 months from 15.12.2014 to 15.12.2015. The samples were exposed outdoors, at $45^{\circ}$ inclination, facing south and placed approximately $1 \mathrm{~m}$ above the ground according to EN 927-3 (2006). The specimens were stabilized at $20 \pm 2{ }^{\circ} \mathrm{C}$ and $65 \% \mathrm{RH}$ before the measurements. Overview of the climatic conditions during 12 months of weathering can be seen in Table 2. 
Table 2. Overview of the climatic conditions at the test site during the exposure period.

\begin{tabular}{|l|c|c|c|c|c|c|}
\hline Variable/month & $\mathbf{0 - 2}$ & $\mathbf{2 - 4}$ & $\mathbf{4 - 6}$ & $\mathbf{6 - 8}$ & $\mathbf{8 - 1 0}$ & $\mathbf{1 0 - 1 2}$ \\
\hline Average temperature $\left[{ }^{\circ} \mathrm{C}\right]$ & 2,0 & 5,2 & 14,1 & 21,2 & 14,4 & 6,7 \\
\hline Average rel. humidity $[\%]$ & 77,3 & 67,1 & 61,5 & 55,2 & 67,8 & 80,6 \\
\hline Total precipitation $[\mathrm{mm}]$ & 15,5 & 19,1 & 36,1 & 33,4 & 31,7 & 13,4 \\
\hline Average global solar rad. $\left[\mathrm{kJ} / \mathrm{m}^{2}\right]$ & 2746 & 10010 & 18602 & 19248 & 11144 & 3494 \\
\hline
\end{tabular}

Note: based on data from Czech University of Life Sciences (2015)

\section{Methods}

The colour and gloss characteristics of the wood were measured using spectrophotometer $600 \mathrm{~d}$ (Konica Minolta, Japan) according to CIE (1986). The equipment was configured to a D65 light source and observation angle of $10^{\circ}$ (CIE L*a*b* standard). Parameters $\mathrm{L}^{*}, \mathrm{a}^{*}$ and $\mathrm{b}^{*}$ and gloss were measured at 8 points on each specimen (Figure 1) at the beginning of the experiment and after 1,2,3, 4, 6 and 12 months.

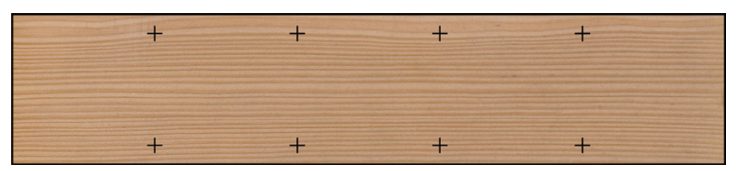

Figure 1. Measurement points for the analysis of the colour changes and their depths.

The total colour changes were calculated according to CIE (1986) using the following equation:

$$
\Delta E=\sqrt{\left(\Delta L^{*}\right)^{2}+\left(\Delta a^{*}\right)^{2}+\left(\Delta b^{*}\right)^{2}}
$$

where: $\mathrm{L}^{*}$ is the lightness from 100 (white) to 0 (black); $\mathrm{a}^{*}$ is the chromaticity coordinate from -60 (green) to +60 (red); $b^{*}$ is the other chromaticity coordinate from -60 (blue) to +60 (yellow).

The depth of colour changes was determined after 3, 6 and 12 months of exposure. The samples were sanded at the measurement points until the colour change (measured continuously by Spectrophotometer Konica Minolta 600d) was in the range of interval where is non-visible by naked eye $\left(\Delta \mathrm{E}^{*}<3\right)$ in comparison with initial state of wood colour before weathering. The depth of these changes was measured by electronic gauge (Mitutoyo, Japan) at the same initial points for each sample (Figure 1).

The surface roughness was determined according to EN ISO 4287 (1997) and EN ISO 4288 (1996) using a profilometer Talysurf Form Intra (Taylor-Hobson, UK). The measurement was carried out in four traversing lengths oriented perpendicularly to the length of the samples over the tangential surface. The parameters were set up according to EN ISO 4288 (1996).

Visual observation of samples with 10x magnifying glass was done during the period of natural weathering test to observe the formation of mould, cracks and other visual defects.

The statistical evaluation was carried out in the software Statistica 12 (Statsoft Ltd., USA) using mean values, standard deviations and linear correlations between the total colour changes and the depth of colour changes at the same measurement points (Figure 1). 


\section{RESULTS AND DISCUSSION}

The total colour difference $\left(\Delta \mathrm{E}^{*}\right)$ showed a systematic trend to increase values with longer duration of exposure (Table 3). The highest mean value of $\Delta \mathrm{E}^{*}$ was determined for spruce, closely followed by poplar wood. The lowest $\Delta \mathrm{E}^{*}$ was observed for oak wood. The visual appearance of the samples is given in Figure 6. The trend of gloss mean values did not show any systematic trend during exposure. Generally, the gently increase was observed for the most cases after 6 months and then large decrease after 12 months of natural weathering test (Table 3 ). The highest change of gloss was observed for pine, the lowest one for oak wood. The lightness $\left(\mathrm{L}^{*}\right)$ values decreased after 12 months of natural weathering for all the wood species (Figure 2). The highest mean value of $\Delta \mathrm{L}^{*}$ after 12 months of weathering was determined both for poplar $\left(\Delta \mathrm{L}^{*}=-30,9\right)$ followed by spruce $\left(\Delta \mathrm{L}^{*}=-30,4\right)$, the lowest one for oak $\left(\Delta \mathrm{L}^{*}=-16,1\right)$. The redness $\left(\mathrm{a}^{*}\right)$ values decreased after 12 months of weathering (Figure 2). The highest mean value of $\Delta \mathrm{a}^{*}$ after 12 months of weathering was determined for Douglas fir $\left(\Delta \mathrm{a}^{*}=-10,2\right)$, the lowest one for black locust $\left(\Delta \mathrm{a}^{*}=-1,4\right)$. The yellowness $\left(\mathrm{b}^{*}\right)$ values also decreased after 12 months of weathering (Figure 2). The highest mean value of $\Delta b^{*}$ was observed for black locust $\left(\Delta b^{*}=-20\right)$, the lowest one for poplar $\left(\Delta \mathrm{b}^{*}=-12,7\right)$.

Table 3. Mean values of $\Delta \mathrm{E}^{*}$ and gloss of tested wood surfaces during 12 months of weathering.

\begin{tabular}{|l|c|c|c|c|c|c|c|c|}
\hline \multirow{2}{*}{ Wood Species } & \multicolumn{2}{|c|}{$\mathbf{1}$ month } & \multicolumn{2}{c|}{ 3 months } & \multicolumn{2}{c|}{$\mathbf{6}$ months } & \multicolumn{2}{c|}{ 12 months } \\
\cline { 2 - 8 } & $\boldsymbol{\Delta \mathbf { E } ^ { * }}$ & gloss & $\mathbf{\Delta \mathbf { E } ^ { * }}$ & gloss & $\Delta \mathbf{E}^{*}$ & gloss & \multicolumn{1}{|c|}{$\Delta \mathbf{E}^{*}$} & gloss \\
\hline Spruce & $11,4(0,7)$ & $12,9(2,1)$ & $13,9(0,9)$ & $12,7(2,7)$ & $18,3(0,8)$ & $16,3(1,5)$ & $34,1(0,9)$ & $9,3(1,7)$ \\
\hline Pine & $8,3(2,1)$ & $8,5(0,9)$ & $10,8(1,8)$ & $9,4(1,7)$ & $15,8(2,4)$ & $14,3(2,3)$ & $28,9(2,3)$ & $9,5(1,9)$ \\
\hline Douglas fir & $10,5(0,8)$ & $6,4(0,8)$ & $10,9(1,4)$ & $6,3(1,0)$ & $16,0(1,3)$ & $8,5(1,3)$ & $28,1(1,6)$ & $7,3(1,2)$ \\
\hline Larch & $11,3(2,9)$ & $5,7(1,2)$ & $12,7(3,8)$ & $5,5(1,5)$ & $17,9(2,7)$ & $8,9(2,4)$ & $30,5(2,6)$ & $7,0(1,6)$ \\
\hline Oak & $3,2(0,7)$ & $6,9(0,7)$ & $4,0(1,5)$ & $8,0(1,4)$ & $12,7(1,5)$ & $11,4(2,0)$ & $23,0(1,2)$ & $5,6(0,8)$ \\
\hline Black locust & $8,4(0,9)$ & $6,9(1,1)$ & $12,5(1,6)$ & $7,0(1,3)$ & $16,0(1,5)$ & $9,0(1,3)$ & $29,6(2,0)$ & $6,3(1,2)$ \\
\hline Maple & $5,2(0,7)$ & $10,4(2,1)$ & $2,9(0,6)$ & $11,9(1,2)$ & $11,7(2,1)$ & $15,8(2,1)$ & $28,5(1,6)$ & $9,3(1,5)$ \\
\hline Poplar & $7,5(1,3)$ & $10,5(0,8)$ & $7,8(2,8)$ & $10,7(1,1)$ & $18,9(5,9)$ & $12,1(2,1)$ & $33,6(2,5)$ & $7,3(1,5)$ \\
\hline Alder & $6,4(2,5)$ & $5,9(1,2)$ & $7,0(2,5)$ & $5,8(1,9)$ & $20,9(2,5)$ & $7,6(2,2)$ & $27,0(2,8)$ & $5,9(2,1)$ \\
\hline
\end{tabular}

Note: Mean values and Standard deviations (in parenthesis) were determined from 24 measurements.

Hon et al. (1985) and Tolvaj and Papp (1999) mentioned that colour reflects the basic chemical composition of wood. If the wood contains a high amount of extractives, the chemical processes of the colour changes quickly take place. Regarding the wood species with low extractive content, the photo-degradation of lignin soon begins with slow but continuous colour change speed. This information is in line with obtained results of an increasing total colour difference $\Delta \mathrm{E}^{*}$. The values $\Delta \mathrm{a}^{*}$ and $\Delta \mathrm{b}^{*}$ followed a similar trend shown in previous studies (Ozgenc et al. 2012, Turkoglu et al. 2015), increased at the beginning of weathering and then decreased. The initial increase in $b^{*}$ values indicates the degradation of lignin (Evans et al. 1992; Müller et al. 2003; Turkoglu et al. 2015). The final decrease of yellowness may be attributed to leaching of decomposed lignin and extractives by water (Turkoglu et al. 2015). The changes in a* values are determined mainly by the changes of the chromophore groups in extractives. The results confirmed that in the early stages of weathering, dark wood trend to become light and light woods become dark or turn into the silver grey colour (Dawson et al. 2008, Saei et al. 2015). 

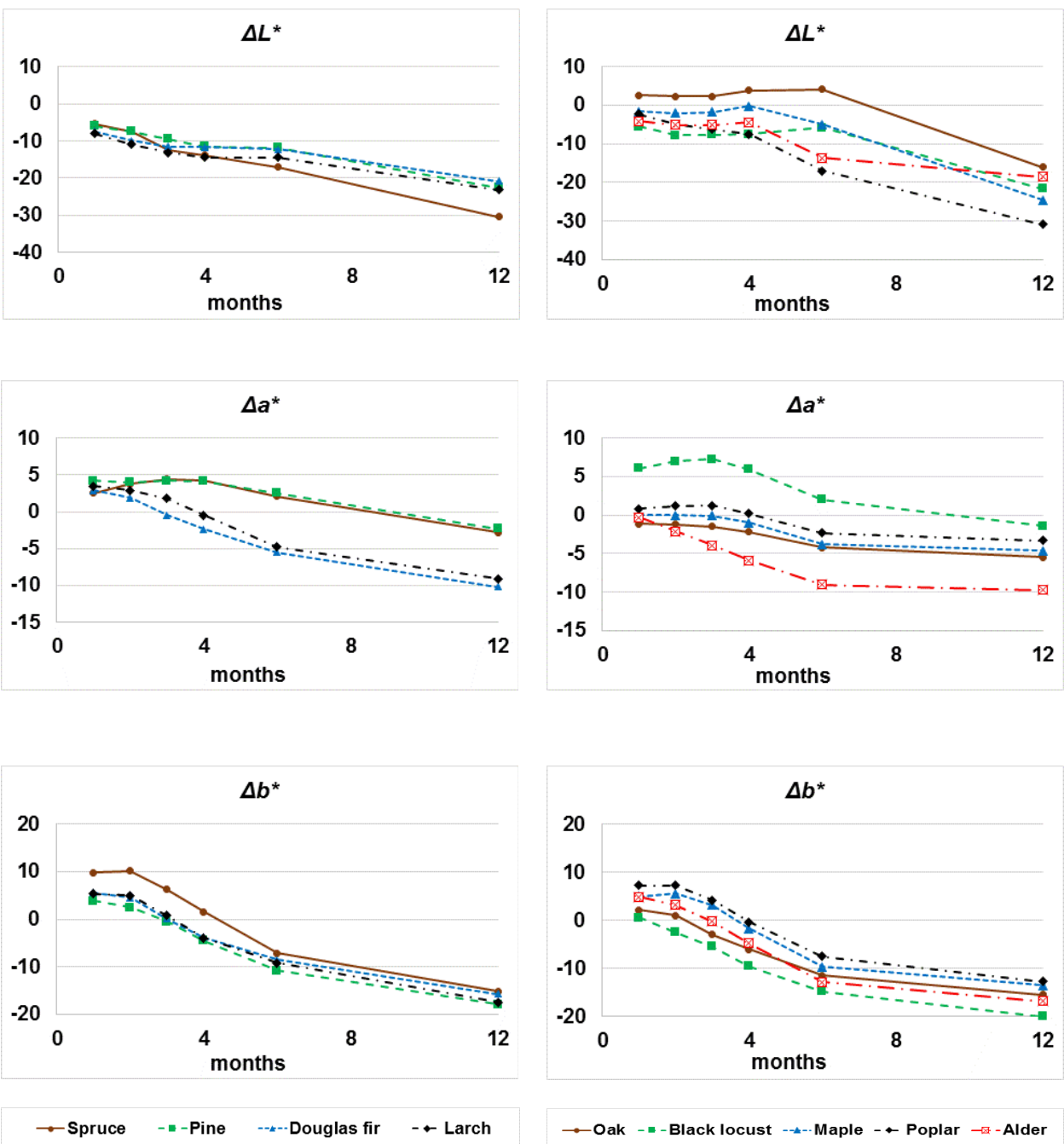

Figure 2. Colour changes of softwoods (left) and hardwoods (right) samples during 12 months of natural weathering.

The depth of colour change was relatively similar for softwood species. For hardwoods, it varied more (Figure 3). The highest value after 12 months of weathering was observed for larch $(1,26 \mathrm{~mm})$ and the lowest one for oak $(0,50 \mathrm{~mm})$. The values of the depth of the colour changes were found to be in high correlation with $\Delta \mathrm{E}^{*}$ for all the wood species (Figure 4). The measurement after 6 months of exposure were done for all the samples, but after 12 months of exposure some samples cannot be measured (alder, poplar, maple) due to the presence of blue-stain fungi, which caused deeper degradation of wood and influenced the colour changes caused only by weathering. The graphs at Figure 4 show the correlation after 6 and 12 months of exposure to natural weathering. The colour changes depth values of all the wood species were in interval given by Feist (1990) and Reinprecht (2008) of $50-2500 \mu \mathrm{m}$ and were found to be in high correlation with $\Delta \mathrm{E}^{*}$ (Figure4). This fact confirms that during early stage of weathering the total colour change of wood surfaces is mainly caused by light decomposition of lignin which in consequence enables radical depolymerization to penetrate deeper into the wood mass. The depth of colour changes of some species (alder, poplar and maple) could not be measured after 12 months of exposure by chosen methodology due to the presence of blue-stain fungi growth in the volume of tested specimens. The penetration of UV radiation depends both on the wood 
density and the wavelengths distribution, denser wood is penetrated less by UV radiation and shorter wavelengths also penetrate less (Rowell 2012).

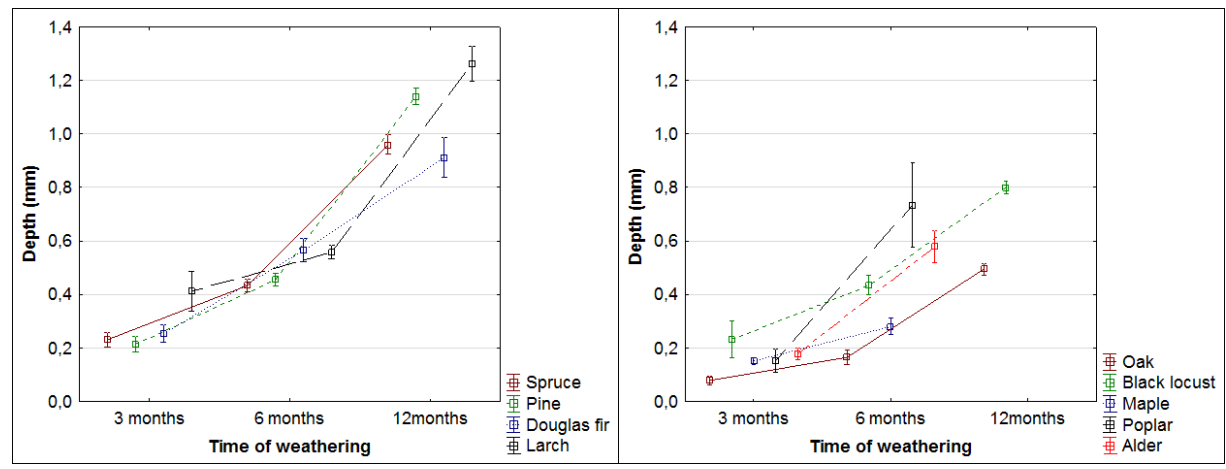

Figure 3. The depth of visible colour changes of softwoods (left) and hardwoods (right) during 12 months of weathering shown as $95 \%$ two sided confidence intervals.
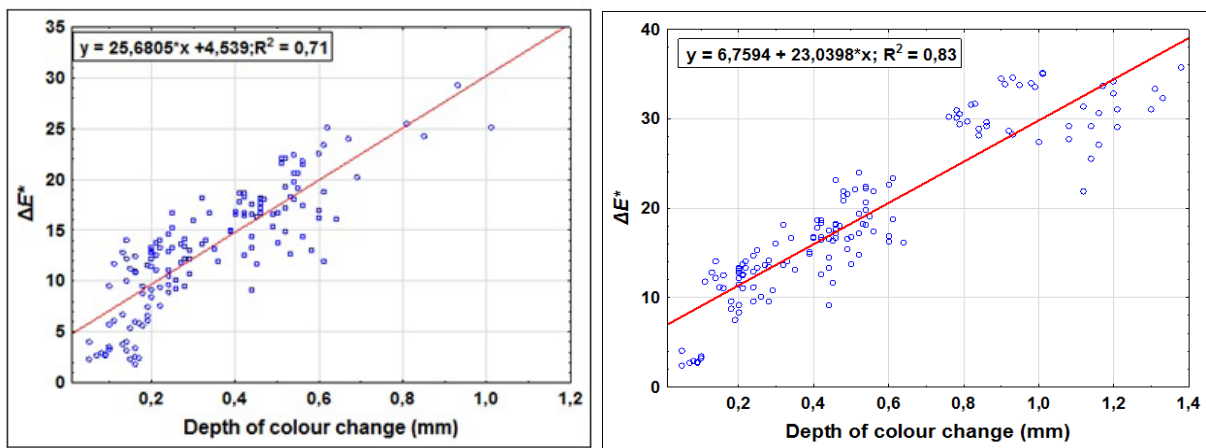

Figure 4. The correlation between total colour change and the depth of colour change during 6 months of natural weathering of nine wood species (left); and during 12 months of natural weathering of six wood species (right).

Note: The measurements were done at the same points before and after the weathering process (see Figure 1).

The roughness values $\left(\mathrm{Ra}^{*}\right)$ increased after 12 months of weathering for all the wood species as expected (Figure 5). The highest mean value of $\mathrm{Ra}^{*}$ after weathering was observed for spruce $(\mathrm{Ra}=$ $25,21 \mu \mathrm{m})$, while the lowest one for alder $(\mathrm{Ra}=7,70 \mu \mathrm{m})$. The roughness measurements confirmed previous studies: value of wood roughness increases with the time of weathering (Nzokou et al. 2011, Tolvaj et al. 2014, Mohebby and Saei 2015) because wood surfaces quickly erode (Williams et al. 2001). Any increased roughness can be related to natural weathering and degradation of the wood polymers (especially lignin) and removed degrading materials due to leaching after rain, mist or dew (Feist 1982). The relatively big differences in roughness values can be explained by the surface erosion occurring mainly in the early wood, due to its thin walled cells and low density (Williams et al. 2001). As the result, the early wood is more and faster degraded (Tolvaj et al. 2014) mainly for softwoods with lower density which was confirmed for spruce wood in presented study (Figure 5). 

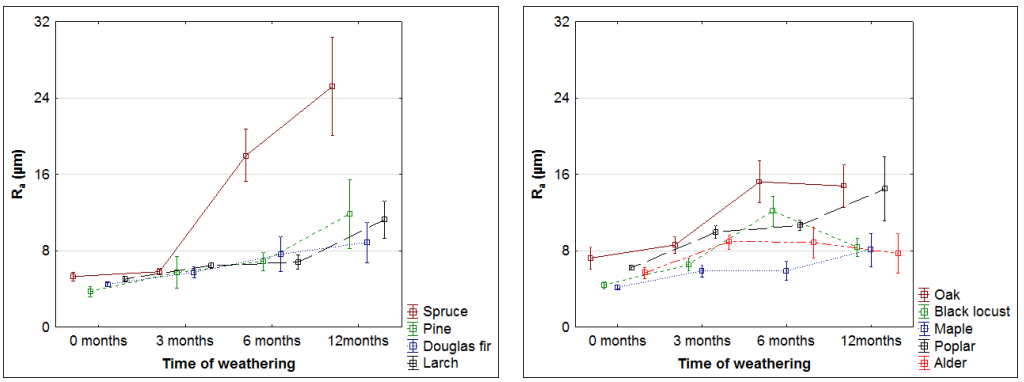

Figure 5. Changes of surface roughness of softwoods (left) and hardwoods (right) during 12 months of weathering shown as $95 \%$ two sided confidence intervals.

The mould growth was first observed at maple, poplar and alder samples after the fourth month of weathering. After 6 months of weathering, wood samples (mostly Douglas fir wood) showed formation of numerous cracks which basically ran in the direction of wood fibres. An appearance of the samples after 12 months of outdoor exposure is demonstrated in Figure 6. Mould and blue-stain fungi growth was observed in those species that are not durable against fungal attack (EN 350-2: 1994) such as maple, poplar and alder samples, especially after the fourth month of exposure. Faster attack of biotic factors was caused by higher mean temperature and the total precipitation after the fourth month of weathering (Table 2).

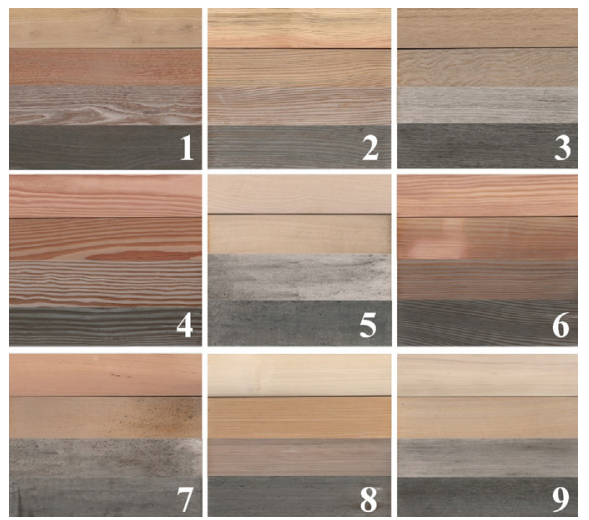

Figure 6. Colour changes of wood samples during 12 months of exposure (from up to down: reference sample, sample after 3, 6 and 12 months of exposure): 1 - locust; 2 - pine; 3 - oak; 4 Douglas fir; 5 - maple; 6 - larch; 7 - alder; 8 - spruce; 9 - poplar

\section{CONCLUSIONS}

The results of this experiment describe surface degradation process of softwoods and hardwoods during 12 months natural weathering in the Czech Republic (Central Europe). It was confirmed that the surface properties of wood such as roughness, colour and formation of cracks are affected by the specific climatic conditions already during initial stage of weathering. But structural differences of wood are still the most important factors which affect weathering characteristics as concluded in the study of other authors. All the colour changes were fast and visible in a very short time about 1 month for all tested species. Also information about the depth of these colour changes of tested wood species, 
which can occur during stocking or longer production time of untreated construction, is given.

A trend of discoloration based on the total colour changes $\left(\Delta \mathrm{E}^{*}\right)$ was observed after very short time of outdoor exposure.

After 12 months of exposure, the lowest and the highest discoloration, according to $\Delta \mathrm{E}^{*}$ values, was recorded for oak $\left(\Delta \mathrm{E}^{*}=23,0\right)$ and for spruce $\left(\Delta \mathrm{E}^{*}=34,1\right)$, respectively.

High correlation between $\Delta \mathrm{E}^{*}$ and the depth of colour changes was determined after 6 months of weathering for all tested species $\left(\mathrm{R}^{2}=0,71\right)$ and after 12 months of weathering for all the softwoods and oak and black locust $\left(\mathrm{R}^{2}=0,83\right)$.

$\Delta \mathrm{a}^{*}$ and $\Delta \mathrm{b}^{*}$ values followed a similar trend: increased at the beginning and then decreased. The $\Delta \mathrm{a}^{*}$ change is determined mainly by the changes of the chromophore groups in extractives and the $\Delta \mathrm{b}^{*}$ change by the lignin degradation and later leaching.

The roughness values increased during outdoor exposure for all tested wood species, the highest was observed for spruce samples (high difference between density of early wood and late wood).

Mould and blue-stain fungi growth was observed in those wood species that are not durable against fungal attack (maple, alder and poplar). Douglas fir was determined as the most liable to formation of the cracks.

\section{ACKNOWLEDGEMENTS}

The authors are very grateful for the financial support of the Internal Grant Agency of the Faculty of Forestry and Wood Sciences, Czech University of Life Sciences, Prague, Project No. A31_16 "The evaluation of the degradation of wood exposed to natural weathering".

\section{REFERENCES}

Brischke, Ch.; Bayerbach, R.; Otto Rapp, A. 2006. Decay-influencing factors: A basis for service life prediction of wood and wood-based products. Wood Material Science and Engineering 1:91-107. DOI: 10.1080/17480270601019658.

Czech University of Life Scences. 2015. Meteostation of the Faculty of Agronomy Department of Agroecology and Biometeorology. Prague, Czech Republic. [Available from] $<$ http:// meteostanice.agrobiologie.cz>

CIE. 1986. Colorimetry. 2nd Edition, CIE Pub. No. 15.2, Commission Internationale de l'Eclairage, Vienna, Austria, 74 pp. ISBN: 3-900-734-00-3.

ČSN 49 0108. 1993. Drevo. Zist'ovanie hustoty [Wood. Determination of the density]. In Czech.

Dawson, B.; Singh, A.; Kroese, H.W.; Schwitzer, M. A.; Gallagher, S.; Riddiough, S.J.; Wu, S. 2008. Enhancing exterior performance of clear coatings through photostabilization of wood. Part 2: coating and weathering performance. Journal of Coatings Technology and Research 5(2):207-219. DOI: $10.1007 / \mathrm{s} 11998-008-9090-\mathrm{z}$. 
EN 350-2. 1994. Durability of wood and wood-based products. Natural durability of solid wood, Part 2: Guide to natural durability and treatability of selected wood species of importance in Europe. European Committee for Standardization, Brussels.

EN 927-3. 2006. Paints and varnishes. Coating materials and coating system for exterior wood, Part 3: Natural weathering test. European Committee for Standardization, Brussels.

EN ISO 4287. 1997. Geometrical product specifications (GPS). Surface texture. Profile method. Terms, definitions and surface texture parameters. International Organization for Standardization, Geneva.

EN ISO 4288. 1996. Geometrical product specifications (GPS). Surface texture. Profile method. Rules and procedures for the assessment of surface texture. International Organization for Standardization, Geneva.

Evans, P.D. 1996. The influence of season and angle of exposure on the weathering of wood. European Journal of Wood and Wood Products 54(3):200-200. DOI: 10.1007/s001070050166.

Evans, P.D. 2008. Weathering and photo-degradation of wood. Development of Wood Preservative Systems, ACS Symposium Series, American Chemical Society (ACS), Washington, DC, USA, pp. 69117. ISBN: 0-8412-3951-7.

Evans, P.D.; Michell, A. J.; Schmalzl, K. J. 1992. Studies of the degradation and protection of wood surfaces. Wood Science and Technology 26(2):151-163. DOI: 10.1007/BF00194471.

Feist, W.C. 1982. Weathering of wood in structural uses. Structural uses of wood in adverse environments, Van Nostrand Reinhold Company, New York, pp 156-178.

Feist, W.C. 1990. Outdoor wood weathering and protection. Advanced in Chemistry, Series No. 225. Washington, DC: American Chemical Society 263-298, Chapter 11. DOI: 10.1021/ba-1990-0225. ch011.

Feist, W.C.; Hon, D.S. 1984. Chemistry of weathering and protection. Advances in chemistry series (207):401-451. DOI: 10.1021/ba-1984-0207.ch011.

Gonzalez de Cademartori, P.H.; Missio, A. L.; Dufau Mattos, B.; Gatto, D. A. 2015. Natural weathering performance of three fast-growing Eucalypt woods. Maderas- Cienc Tecnol 17(4): 799808. DOI: $10.4067 / \mathrm{S} 0718-221 \mathrm{X} 2015005000069$.

Hon, D.N.S.; Shiraishi, N. 2001. Wood and cellulose chemistry. New York und Basel: Marcel Dekker Inc. 914 p. ISBN: 0824700244.

Hon, D.N.S.; Chang, S.T. 1984. Surface degradation of wood by ultraviolet light. Journal of Polymer Science: Polymer Chemistry Edition 22(9):2227-2241. DOI: 10.1002/pol.1984.170220923.

Hon, D.N.S.; Chang, S.T.; Feist, W.C. 1985. Protection of wood surfaces against photooxidation. Journal of Applied Polymer Science 30(4): 1429-1448. DOI: 10.1002/app.1985.070300410.

Hon, D.S.; Feist, W.C. 1986. Weathering characteristics of hardwood surfaces. Wood Science and Technology 20(2):169-183.

Kataoka, Y.; Kiguchi, M.; Williams, R.S.; Evans, P.D. 2007. Violet light causes photodegradation of wood beyond the zone affected by ultraviolet radiation. Holzforschung 61(1):23-27. DOI: 10.1515/ HF.2007.005. 
Kropf, F.W.; Sell, J.; Feist, W.C. 1994. Comparative weathering tests of North American and European exterior wood finishes. Forest Products Journal 44(10):33-41.

Macleod, I.T.; Scully, A. D.; Ghiggino, K. P.; Ritchie, P. J. A.; Paravagna, O. M.; Leary, B. 1995. Photodegradation at the wood-clearcoat interface. Wood Science and Technology 29(3): 183-189. DOI: $10.1007 / \mathrm{BF} 00204584$.

Mohebby, B.; Saei, A.M. 2015. Effects of geographical directions and climatological parameters on natural weathering of fir wood. Construction and Building Materials 94:684-690. DOI: 10.1016/j. conbuildmat.2015.07.049.

Müller, U.; Rätzsch, M.; Schwanninger, M.; Steiner, M.; Zöbl, H. 2003. Yellowing and IRchanges of spruce wood as result of UV-irradiation. Journal of Photochemistry and Photobiology B: Biology 69(2):97-105. DOI: 10.1016/S1011-1344(02)00412-8.

Nzokou, P.; Kamdem, D. P.; Temiz, A. 2011. Effect of accelerated weathering on discoloration and roughness of finished ash wood surfaces in comparison with red oak and hard maple. Progress in Organic Coatings 71(4):350-354. DOI: 10.1016/j.porgcoat.2011.03.028

Östman, B. L. 1983. Surface roughness of wood-based panels after aging. Forest Products Journal 33(7/8):35-42.

Ozgenc, O.; Hiziroglu, S.; Yildiz, U. C. 2012. Weathering properties of wood species treated with different coating applications. BioResources 7(4): 4875-4888. DOI: 10.15376/biores.7.4.4875-4888.

Ozgenc, O.; Okan, O.T.; Yildiz, U.C.; Deniz, I. 2013. Wood surface protection against artificial weathering with vegetable seed oils. BioResources 8(4): 6242-6262. DOI: 10.15376/ biores.8.4.6242-6262.

Pandey, K. K. 2005. A note on the influence of extractives on the photo-discoloration and photo-degradation of wood. Polymer Degradation and Stability 87(2): 375-379. DOI: 10.1016/j. polymdegradstab.2004.09.007.

Reinprecht, L. 2008. Ochrana dreva [Wood protection]. Handbook. Technical University in Zvolen-Slovakia. ISBN: 978-80-228-1863-6.

Rowell, R. M. 2012. Handbook of wood chemistry and wood composites. CRC press.

Saei, A.M.; Mohebby, B.; Abdeh, M.R. 2015. Effects of oleothermal treatment and polydimethylsiloxane (PDMS) coating on natural weathering of beech and fir woods. Maderas- Cienc Tecnol 17(4):905-918. DOI: 10.4067/S0718-221X2015005000079.

Singh, T.; Singh, A.P. 2012. A review on natural products as wood protectant. Wood Science and Technology 46(5):851-870.

Teacà, C.A.; Rosu, D.; Bodîrlàu, R.; Rosu, L. 2013. Structural changes in wood under artificial UV light irradiation by FTIR spectroscopy and color measurements - a brief review. BioResources 8(1):1478-1507. DOI: 10.15376/biores.8.1.1478-1507.

Temiz, A.; Yildiz, U.C.; Aydin, I.; Eikenes, M.; Alfredsen, G.; Çolakoglu, G. 2005. Surface roughness and color characteristics of wood treated with preservatives after accelerated weathering test. Applied Surface Science 250(1):35-42. DOI: 10.1016/j.apsusc.2004.12.019.

Tolvaj, L.; Faix, O. 1995. Artificial ageing of wood monitored by DRIFT spectroscopy and CIE $L^{*} a^{*} b^{*}$ color measurements. 1. Effect of UV light. Holzforschung 49(5):397-404. DOI: 10.1515/ hfsg.1995.49.5.397. 
Tolvaj, L.; Molnar, Z.; Magoss, E. 2014. Measurement of photodegradation-caused roughness of wood using a new optical method. Journal of Photochemistry and Photobiology B: Biology 134:23-26. DOI: $10.1016 /$ j.jphotobiol.2014.03.020.

Tolvaj, L.; Papp, G. 1999. Outdoor weathering of impregnated and steamed black locust. ICWSF'99 conference, Missenden Abbey (UK), pp. 112-115.

Turkoglu, T.; Baysal, E.; Toker, H. 2015. The Effects of Natural Weathering on Color Stability of Impregnated and Varnished Wood Materials. Advances in Materials Science and Engineering. Volume 2015 (2015), Article ID 526570, 9 pages. DOI: 10.1155/2015/526570.

Williams, R.S.; Feist, W.C. 1999. Water repellents and water-repellent preservatives for wood (Vol. 109). Forest Products Laboratory.

Williams, R.S.; Knaebe, M.T.; Feist, W.C. 2001. Erosion rates of wood during natural weathering. Part II. Earlywood and latewood erosion rates. Wood and Fiber Science 33(1):43-49.

Williams, R.S. 2005. Weathering of wood. Handbook of wood chemistry and wood composites. . Madison: CRC Press. ISBN: 1439853800.

Xie, Y.; Krause, A.; Militz, H.; Mai, C. 2008. Weathering of uncoated and coated wood treated with methylated 1, 3-dimethylol-4, 5-dihydroxyethyleneurea (mDMDHEU). Holz als Roh-und Werkstoff 66(6):455-464. DOI: 10.1007/s00107-008-0270-4. 